無カタラーゼ血液症の一家系について

\author{
新井誠四郎・内田 稔・東江 良昭*・園山 昇*
}

\title{
A case report of an acatalasemia family
}

\author{
Seishiro Arai - Minoru Uchida - Yoshiaki Agarie* - Noboru Sonoyama*
}

\section{ま えがき}

無カタラーゼ血液症は, 1946年 (昭和21年) 高原によ り発見され，1947年初めて記載せられた疾患で，笊の本 態は，血液中にカタラーゼ酵素を欠如するという先天性 の体質異常症である.

高原 ${ }^{1)}$ によれば, 本症は日本人 38 家系 74 例, 朝鮮人 1 家系 3 例, スイス人 3 家系 11 例計 42 家系 88 例が報告され ている.

本症は一種特有な進行性壊疽性口内炎を起こし，また， 同一家系の人に多く現われ，本症の両親の約 $70 \%$ は血族 結婚であるといわれている.

本症家系の同胞中には血中のカタララーゼ活性が正常な ものと, 正常人の約半分のものとがあり, 後者を低カタ ラーゼ血液症と呼び, 遺伝子の保因状態をつとめ, メン デルの劣性遺伝方式で遺伝しているといわれる.

高原の報告以来諸家 ${ }^{2) ~ 14)}$ の発表を散見するが，最近， 著者らは，たまたま本症に遭遇し，また，この家族とそ れに連なる数人の同胞の協力が得られたため, その血液 の生化学的検索を行い興味ある結果を得たので, その一 家系を中心に報告する.

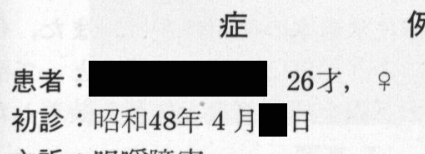

主訴 : 咀嚼障害

家族歴：患者は同胞 5 名中の第 3 子で, 両親, 同胞共 に生存している，両親と末子はともに著患を知らず，長 男は 5 年前より肺結核にて入院加療中であり，次男は 22 才の時より歯槽膿漏症とのことで某歯科で多数歯の抜歯

日本歯科大学口腔外科学教室第一講座（主任 : 宇賀春雄教授）

* 日本歯科大学口腔外科学教室第二講座 (主任 : 園山 其教授) First Department of Oral Surgery, Nippon Dental College. (Chief : Prof. Haruo Uga)

* Second Department of Oral Surgery, Nippon Dental College. (Chief : Prof. Noboru Sonoyama)

受付 昭和 50 年 2 月 3 日
を受け上下顎ともに局部床義歯を装着している．また， 3 男は， 2 才の時に左側片側性鬼唇並びに顎裂にて手術 を受けている.

既往歴：全身的には，特記すべき事項はない。

局所的には，12才頃より小罒歯部，大曰歯部の弛緩動 摇, 自然脱落を認めるも著明な症状がなかったため, 一 度も歯科医のもとを訪れたことはなかったという，歯牙 脱落時の疼痛は軽微であったため，そのまま放置，歯牙 脱落部は 7 日ないし10日で治癒したとのことである. 最 近咀嚼障害を覚え，義歯装着を希望し，某歯科を受診す るも，歯槽頂部に付着する小帯様索状物のために義歯作 製困難とのことで本院を紹介され来院したものである.

現症：体格栄養状態はともに中等度であり，顔貌所見 では，顔色は色白であり瘦型で繊細な感を受ける（写真 $1)$.

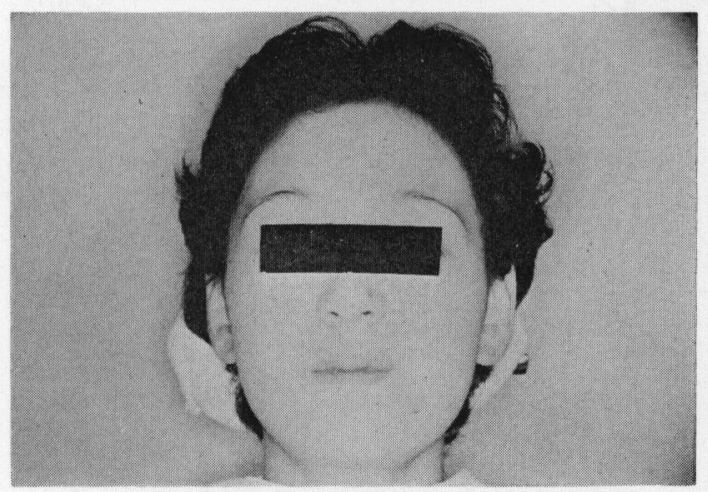

写真 1

口腔内所見では, 残存歯牙は $\frac{3 \mid 1}{73}$ の 5 歯であり, 残 根状態となっている 7 を除さ他はいずれも歯根の露出を 見, 捻転傾斜し, 弛緩動摇が認められる. また, 周囲歯 肉粘膜は健康色を呈し, 潰瘍形成などの所見は認められ ない、歯槽部は, 左右頓粘膜より歯槽頂におよぶ強靶な 小帯状を呈した痗痕様の索状物が認められ，開口時には 粘膜が緊張することにより歯肉粘膜が直接頓粘膜に移行 
する䘽を是する。

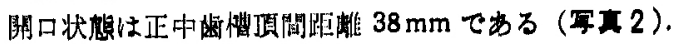

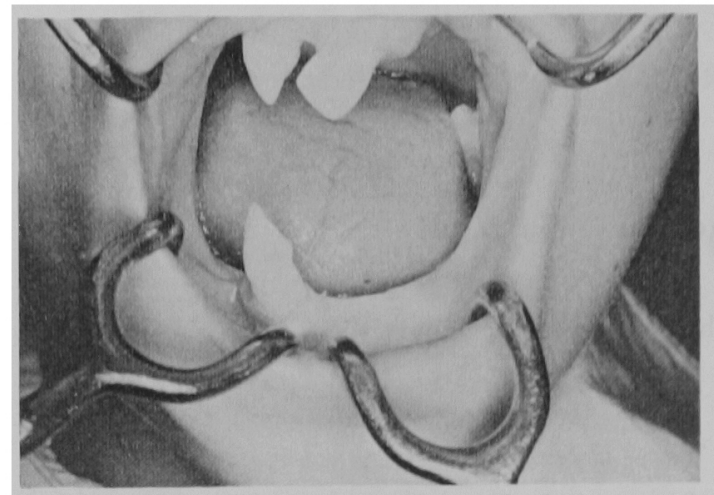

写真 2

なお X線所見ならびに血液一般検查などには巽常が䏸 められなかった。

姏而ならひに経過：上記の所見より小带様索状物の切

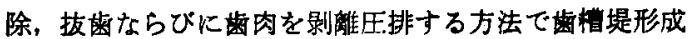
手術を施行した。

術中, 創倁洗浄の目的で過酸化水素水を塗布したとこ ろ，血液は発泡せず，一粰にして黒褐色に変したため， 無カタラーゼ血液症を疑った。 そこで生化学的にカタラ 一ゼ活性の测定を行ったところ無カタラーゼ血液应であ ることが判明した.

军真 3 は，術中のガーゼであり，右が過酸化水素淘布 により，瞬時に黒褐色に変じたるのである.

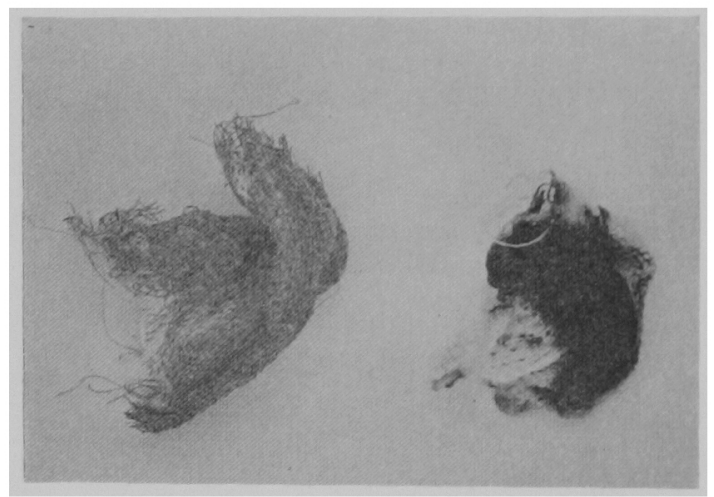

写真 3

写真 4 は，正常者並びに患者血液を小試験管にとり過 酸化水素水の一滴を滴下したところ, 右の患者のものは 発泡が認められない。

写真 5は，その24時間後の所見で，右は患者のもので あるが，血色素の最終分解産物である Propentdyopent と思われる淡黄色透明な上清液と，变性蛋白と考えられ る Denatured protein および Fe よりなる灰白色の沈

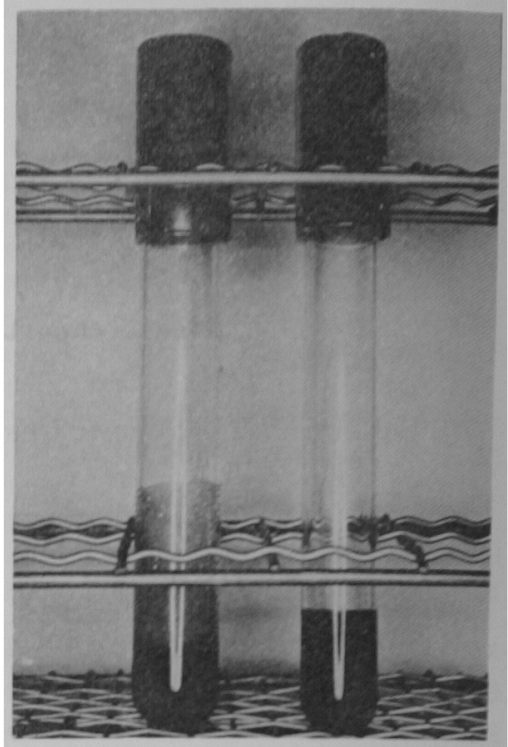

写共 4

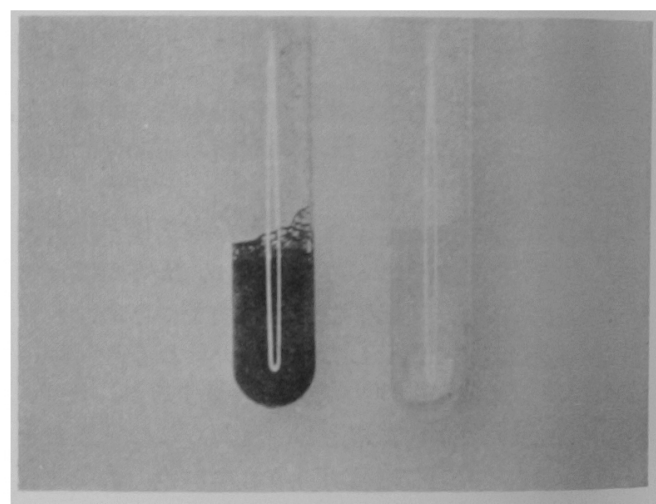

军呈 5

殿物とに分離した。

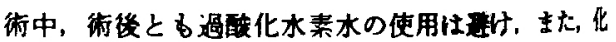

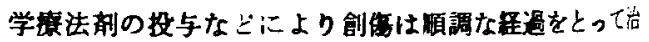

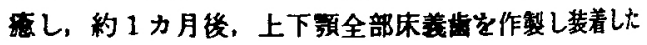

(写卉 6，7)。

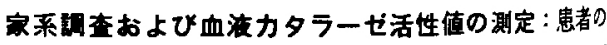
家系は图1に示す通りで，患者は長女であるか，その雨

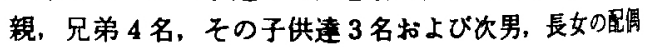
者の計11名である. 口が男性で○が性であり，黑〈荃 りつぶしたるのはカタラーゼ血液症者を表わしている。

カタラーゼ活性の测定はVon Euler ならびに Herbert が考案改良した方法の変法である藤森らの方法を考考と した ${ }^{7), 15)}$.

すなわち，過酸化水素消失量を過マンガン酸かり楛 定する方法によった. 


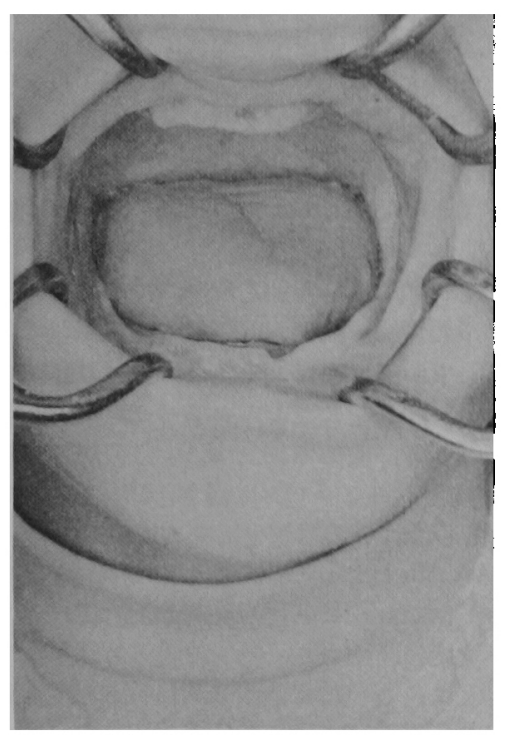

写真 6

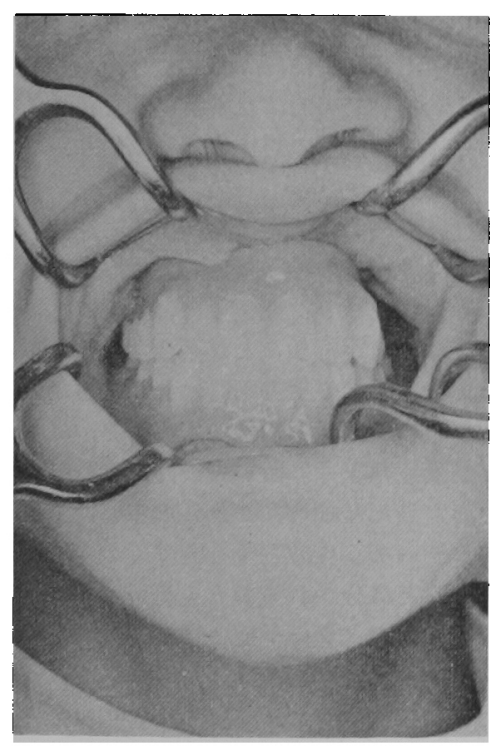

写真 7

表1は，11名の被験者のカタラーゼ值である．次男と 長女がタタラーゼ值 0 を示している。

图2は，被験者11名のカタラーゼ活性值をダラフに現 わしたすのであり，2名が無カタラーゼで7名が低カタ ラーゼ，次男，長女の配偶者は正常である.

写公8は家族の調查により発見された無カタラーゼ血 液应である次男の顔貌所見で; 年令は30才である.

写面9は，その口腔内所見であり，残存歯牙は 7 歯で， 患者である姉の初診時の口腔内所見汇酷似している。

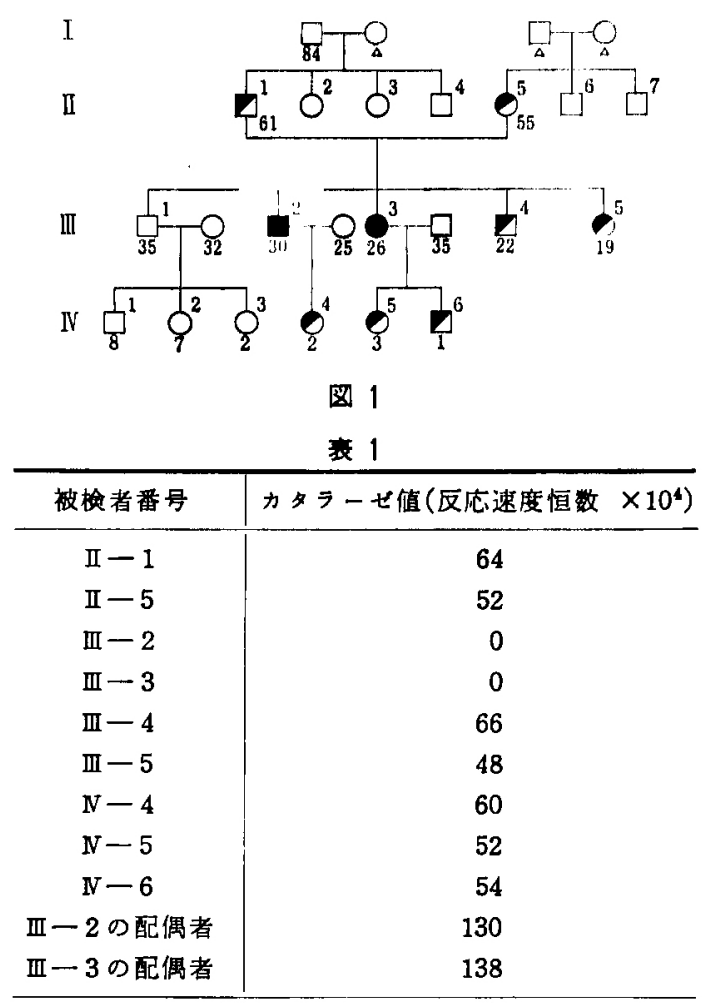

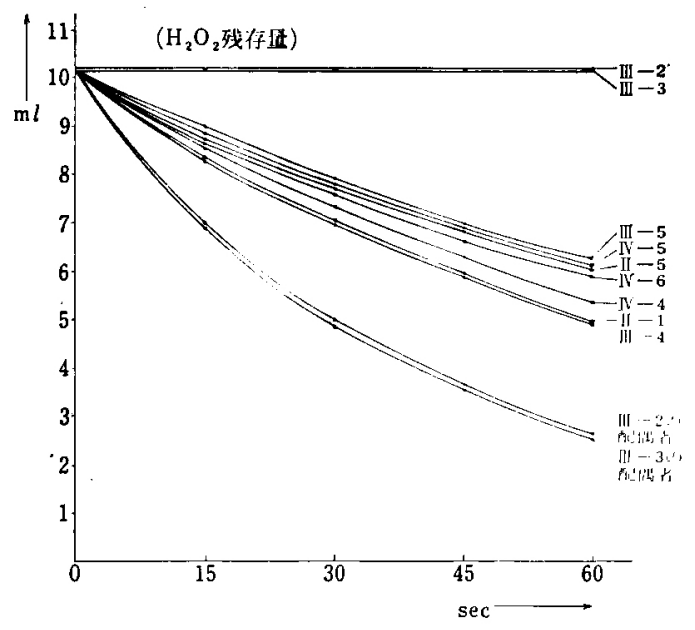

図 2

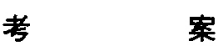

本症の研究の発端は，1946年（昭和21年）高原が10才 の少女を診察したことに始まる。すなわち61画根部を中 心とする骨壊疽に対し手術を行い，切除した創面を清を 


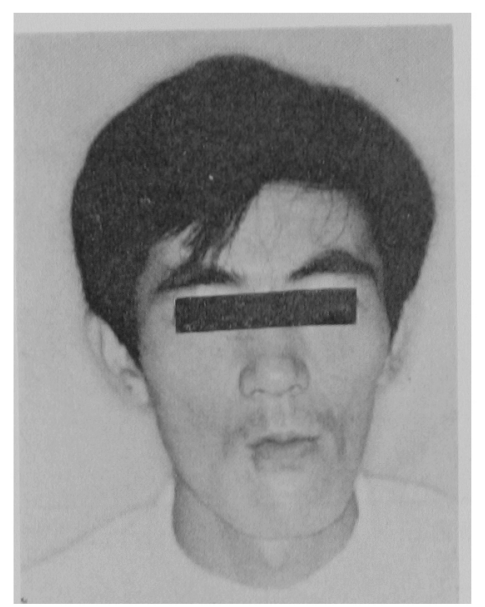

军声 8

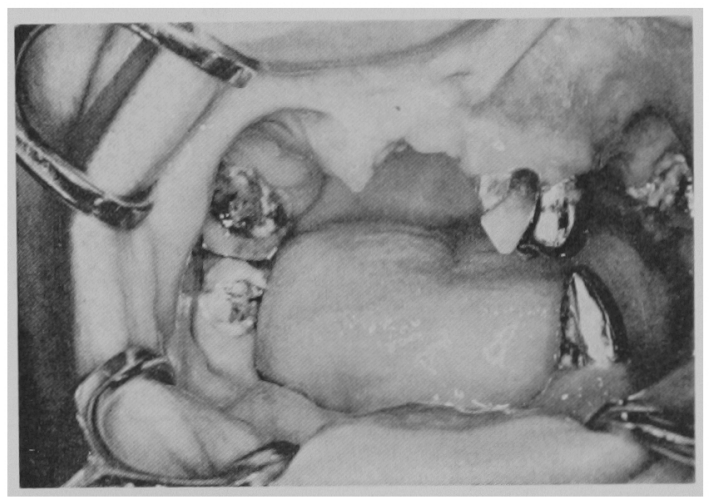

写真 9

拭する目的で $1 \%$ 過酸化水素水を注加したところ, 合面 の血液が瞬時に濃い黑褐色に变わり，その際気泡の出な いのに警き，硝酸銀の境を過酸化水素水の塿と誤って使 用したものと直感したと本症発見当時の模様を記述して (る ${ }^{1,8)}$.

すへての生体は正常な代謝過程に和いて，その組織中 に $\mathrm{H}_{2} \mathrm{O}_{2}$ を産生するが，この $\mathrm{H}_{2} \mathrm{O}_{2}$ はカタラーゼ醉素の 触某作用によって, 水と酸素とに分解されており，それ により組織細胞は $\mathrm{H}_{2} \mathrm{O}_{2}$ の破壊作用から防渵されている と従来考えられてきた。

1947年高原による本症に関する報告以来, 莫然とカタ ラーゼを生物の生存上欠くべからざるるののことく考え られていたものが無カタラーゼ血液怔の出現により，カ タラーゼは, 人体の生存上絶体不可欠のbのではないと の問題が提起されたのである.

無カタラーゼ血液症の発見は，血中カタラーゼの持つ 意義に関して，特に生体内代謝過程の研究に貴重な一石
抄じ，以米体怔についての血洨の特有性，免疫化学的方

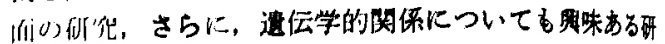
珄分倠められている。

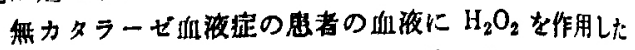

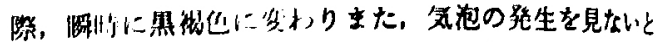

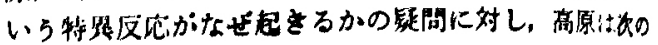
よらに裞明している。

正常人血液に $\mathrm{H}_{2} \mathrm{O}_{2}$ を加えると，近液中に含まれるか

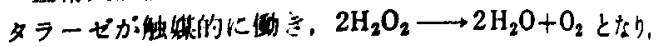

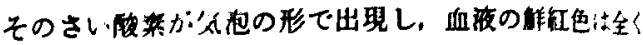

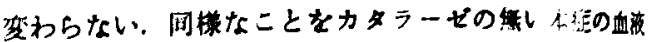
についてて行うと，淤加された $\mathrm{H}_{2} \mathrm{O}_{2}$ : :分解されることな

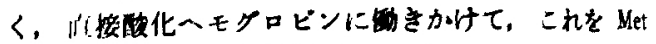

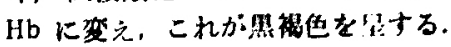

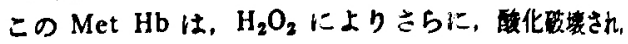

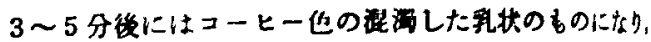

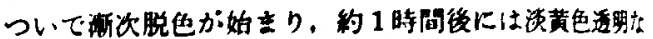

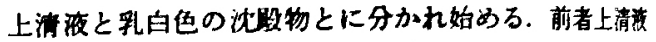
は血色素の䅂分解産物である Propentdyopent であり， 後者沈期物は变性虽白 Denatured protein と $\mathrm{Fe}$ よ) 成るものであろ.

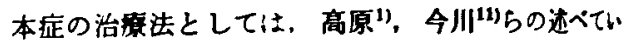
ることく，原因が先天的体貝異常に基くため，根本的虑

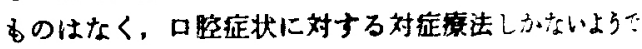
ある.

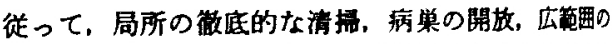
作用を持つ抗生物質の投与などが效果があるよらでる。 なお，ある程度進行した在例では，早期に外科尞法を元

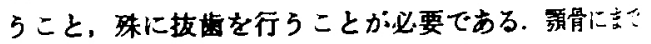
進んた場合には腐骨の除去を行わねばならない。

次に，本应の遗后网俰についてみると，高原が，焦 タラーゼ血液庭の家系において、詳細にそのカタラーゼ 活性值を剧定したところ、これらの中には正常家和正 常者のカタラーゼ活性值と全く同等值のものと，ほ活半 量を示するのとに分かれることを見いたし，この半分值 を示すすのを低カタラーゼ症と命名した。

これを無カタラーゼ血液应の家系にあてはめると，そ

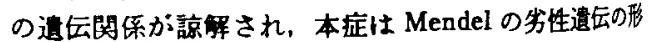
式により遗卮していることが判明した。

かくして，この低かタラーゼ血液应が，無カタラーゼ 症の無生に対するCarrier State（保因状態）をつと》 ていると考えられるに至った.

すなわら，高原の謂査によれば
1) $\bigcirc \times 0$ の子供は皆 $\mathrm{O}$.
2） $\because 0$ の子供はのまたは○,
3） $\bigcirc \times$ の子供は皆 $D$,
4）の×の の子供は○，またはの，または○、
5）の×○の子供は○，またはD，

○は正常者，のは低カタラーゼ血液症者，の繁が 
ラーゼ血液症者を表わし，その組み合わせの結果はメン デルの劣性遗云方式をよく満足している。

本症家系では患者の雨親と患者兄弟との成係は，4)の 組み合わせ，患者と子供との関係は，3）の組み合わせに 該当するるのであった。

\section{結熟}

1)

の26才の女性で阻喼障宫を主訴 に来院した患者について，拔齿ならびに紫模堤形成手術 施行中, 偶然無カタラーゼ血液症を発見した。

2）家族の調查を行ったところ，両親かともに低カタ ラーゼ血液症であり，患者のはかにす51名の無カタラ 一ゼ血液症を発見しえた。

3）患者の兄弟 2 名，その子供達 3 名に低カタラーゼ 血液症を発見した。

4）カタラーゼ值測定の結果調查しえた患者家族 9 名 恃，すべて無カタラーゼあるいは低カタラーゼの活性値 を示し，正常値を示すすのはなかった．

5）メンデルの劣性遺云の形式通りに現われているこ とが判明した。

稿を䅂わるにあたり，血液の生化学的検索に終始ご指 導とご援助を頂いた本学生化学教室三代幸彦教授ならび 飞桐村和子助教授に深く感謝致します。

この論文要旨は，第19回日本口腔外科学会総会（昭和 49年11月 2 日，大阪）において発表した。

\section{文献}

1）高原沙夫：無カタラーゼ血夜症（Acatalasemia）
ならびにそれに因るロ腔疾急について。、科能 $15: 83 \sim 921966$.

2）林一，他：俓力ターセの1症例、口科战 3 ： 254 257 1954 .

3）久原勝之，他：兄妹に現われた嫣カタラーゼ症追 加. 臨床橉科 $26: 12 \sim 141954$.

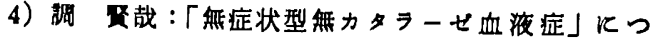
いて. 耳峥 $28: 121 \sim 1231956$.

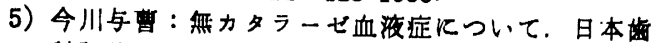
科部諳 $180: 30 \sim 311957$.

6）栃原人：無カタラーゼ血症の 1 例. 梅科学報 $58: 401 \sim 4051958$

7）藤森春樹，他：無カタラーゼ血液症の 3 症例，耳 挣 $34: 213 \sim 2161962$.

8）高原流夫：無力タラービ血液症. 人類造伝学䧴誌 $7: 37 \sim 591962$.

9）折田洋造：無カタラーゼ血症におけるへモクロピ ンの分解について. 人類臬伀学雑誌. $7: 163$ 1891962.

10）今川与曹, 他 : 無カタラーゼ血液症の 2 例につい $\tau$, 口病誌 $29: 22 \sim 271662$.

11）今川与曹，他：無カタラーゼ血液症の一家系につ いて. 口病誌 $29: 28 \sim 331962$.

12）今川与曹, 他 : 無カタラーゼ血液症の二家系につ いて. 口病誌 $29: 34 \sim 371962$.

13）松島 睦，他：人の無カタラーゼ症の遺伝的異質 性. 人類造伝学雑誌 $9: 46 \sim 561964$.

14）無カタラーゼ血液症の遗云学と生化学. 日本人類 遗伝学会第 9 回大会諥演要旨 1964,232 頁.

15）上代晧三，中尾喜久：血色素の生理と臨床. 第 1 版, 医学曹院, 東京, 1958, 226 頁. 